\title{
Myndigheters externa relationer - en fràga om kvinnligt och manligt ledarskap?
}

I denna studie prövas om det finns ett positivt samband mellan myndighetschefers kön och närheten i myndigheternas relationer till viktiga externa aktörer. Syftet är att belysa frågan om fler kvinnor på ledande positioner inom statsförvaltningen bidrar till att förändra myndigheternas arbetsformer. Att kvinnor och män har olika ledarstilar och kompetenser är ett vanligt argument för att en jämnare könsbalans på ledande positioner är önskvärd. Det finns dock mycket lite empirisk forskning som undersöker om sådana potentiella könsskillnader faktiskt leder till att organisationer presterar olika. Den typ av prestationer som här studien fokuserar på är i vilken utsträckning statliga myndligheter lyckas etablera nära relationer till den politiska ledningen. Undersökningen grundar sig på information insamlad direkt från myndigheterna, samt på en enkätstudie besvarad av 157 svenska myndigheter år 2009. Resultaten pekar mot att myndigheter med kvinnliga chefer inte har en närmare relation till regeringen och ansvarigt departement, snarare tvärtom.

\section{Inledning}

Den manliga dominansen på ledande positioner i det svenska samhället sjunker och statsförvaltningen är inget undantag. Mellan 1993 och 2008 minskade andelen män bland myndighetschefer från 83 till 62 procent och bland generaldirektörer och landshövdingar är den ännu något lägre: 59 respektive 57 procent (Propposition 2008/2009:1).

Denna förändring kan anses principiellt viktig (Mill, 1869; Young, 1990; Dahl, 2000; Phillips, 2000), men förespråkare för en jämnare könsfördelning bland förvaltningschefer har även framfört mer substantiella argument. Ett sådant argument är att en väl fungerande förvaltning kräver att man tar tillvara kvinnors specifika kompetens (KRUS, 2010). Logiken bakom detta argument är att de könsroller (de Beauvoir, 1949; Hirdman, 1990; Butler, 1993), som till stor del styr vilka livserfarenheter människor ackumulerar, i förlängningen också leder till att kvinnor och män, som grupper, utvecklar olika preferenser och kompetenser. Kvinnor antas till exempel vara bättre på, och lägga större 
vikt vid, relationer och platta organisationsstrukturer än vad män gör (Rosener, 1990; Berg, 2000; Wahl, 2003; Wahl et al., 2001). Fler kvinnor på ledande positioner inom statsförvaltningen skulle alltså kunna bidra till en förändring och förbättring av förvaltningens arbetsformer och arbetssätt. Kvinnors större sociala kompetens skulle exempelvis kunna medföra att de fungerar bättre som representanter för sina organisationer utåt i förhållande till externa aktörer (Bass, 1996; Damanpour \& Schneider, 2009).

Det finns emellertid ganska lite forskning som har undersökt om det finns något empiriskt stöd för detta påstående. Leder fler kvinnliga chefer till att verksamheten i organisationerna bedrivs på ett annorlunda, eller till och med bättre sätt än de som styrs av män? Syftet med denna artikel är att belysa denna fråga genom att studera om myndigheters relation till två av de externa aktörer som är absolut viktigast för dem - regeringen och det ansvariga departementet - förbättras om myndigheterna leds av kvinnor.

Artikeln är uppbyggd så att den inleds med en kort genomgång av tidigare forskning om huruvida, och i så fall på vilket sätt kvinnor och män agerar olika som chefer, samt vilka konsekvenser detta kan få för hur organisationer styrs och presterar. Därefter följer en redogörelse för den data som studien grundar sig på och en presentation av de empiriska resultaten. Analysen av dessa resultat indikerar att det finns ett samband mellan myndighetschefers kön och myndigheters relationer till deras politiska överordnanden, men att detta samband ser annorlunda ut än väntat. Artikeln avslutas med ett avsnitt där slutsatser och tänkbara implikationer av detta resultat diskuteras.

\section{Ledarstilar och externa nätverk}

Som nämnts inledningsvis finns det inte så mycket forskning som fokuserar på de organisatoriska effekterna av kvinnligt och manligt ledarskap. Däremot har betydligt fler forskare ägnat sig åt att studera vad som karaktäriserar kvinnligt respektive manligt ledarskap. En del av denna forskning pekar mot att kvinnor och män tillämpar olika ledarstilar, både internt gentemot de egna medarbetarna, t.ex. vilken roll de spelar i utformningen av organisationens strukturer, procedurer och praktiker (Eagly \& Johnson, 1990; Bass et al., 1996), och externt gentemot andra aktörer, t.ex. i vilken utsträckning och hur de nätverkar med andra aktörer och vilka dessa aktörer är (Fox \& Schuhmann, 1999; Jacobson et al., 2009). För denna studie är forskningen om eventuella skillnader i nätverksbeteende mellan kvinnliga och manliga ledare särskilt relevant och den kommer därför att stå i fokus i diskussion nedan.

Rent generellt beskrivs kvinnliga chefer ofta som mer interaktionsinriktade. Deras ledarstil är mer demokratisk och inkluderande, vilket bland annat inne- 
bär att de lägger större viktigt vid att kommunikationen ska fungera väl mellan medarbetarna inom organisationen, men också mellan organisationen och externa aktörer (Eagly \& Johnson, 1990; Fox \& Schuhmann, 1999. Se även Wahl, 2003). Att information ska vara öppen och tillgänglig för alla och inte användas som ett maktmedel för att utesluta vissa grupper, eller för att kontrollera kritiska situationer verkar vara en inställning som får starkt stöd bland kvinnliga chefer (Rosener, 1990).

Kvinnliga ledare framhålls ofta även som mer transformativa (Bass at al., 1996; Eagly, 2007. Se även Westerberg, 1997). Transformativt ledarskap innebär att ledaren motiverar sina anställda genom att fungera som en karismatisk och inspirerande förebild som tar individuell hänsyn till de anställdas behov och stimulerar dem intellektuellt.

Gemensamt för transformativa och interaktionsinriktade ledarstilar är att de är kopplade till sättet att betrakta och prioritera relationer. I fortsättningen kommer jag därför, för enkelhets skull, använda "relationsinriktad ledarstil" som ett samlingsbegrepp för dessa egenskaper.

Anledningen till att kvinnor förknippas med relationsinriktade ledarstilar i högre grad än män brukar förklaras med att deras sociala kompetens i allmänhet är mer välutvecklad; de är mer hjälpsamma, förstående och empatiska än män. En sådan ledarstil kan sägas ligga i linje med traditionellt kvinnliga egenskaper, som till exempel att vara vårdande och inkluderande (Gilligan, 1982; Bass \& Avolio, 1997; Eagly, 2007), och den möjliggör på så sätt för kvinnor att framstå som trovärdiga ledare, samtidigt som de inte uppfattas vara alltför maskulina. Traditionella ledaregenskaper brukar nämligen förknippas med maskulinitet (Mansbridge, 1991; Holmquist, 1997; Holgersson, 2003; Eagly, 2007).

Det finns dock studier som pekar mot att kvinnors mer relationsinriktade ledarstil inte automatiskt medför att de även utvecklar ett mer omfattande professionellt nätverk. En komparativ studie av ledare inom politik och näringsliv i 24 länder uppvisar inga större skillnader mellan kvinnor och män (Moore \& White, 2000; Bakker, 2000). Enkätundersökningen Ledarskap i förändring, som bland annat riktades till över 500 myndighetschefer i Sverige år 2001, visar till och med tvärtom att kvinnliga myndighetschefer överlag har färre professionella kontakter med ledande personer från andra eliter (DjerfPierre, 2007. Se även Ibarra, 1993; Jacobson, 2009). Detta kan förstås som ett tecken på att kvinnor utestängs från homosociala, manliga nätverk (Kanter, 1977; Wahl et al., 2001; Holgersson, 2003).

Det finns även flera forskare som menar att det inte finns några entydiga resultat som pekar mot att kvinnor och män faktiskt praktiserar olika ledarsti- 
lar (Epstein et al., 1991; Eagly 2007; Jacobson et al., 2009). Jane Mansbridge (1991) påpekar till exempel att kvinnors mer relationsinriktade ledarstil kan bero på att de fortfarande är relativt nya på ledande positioner och att de därför inte riktigt har hittat formen än. En annan tänkbar förklaring som framförts av Camilla Stivers (1993) och som får stöd i en studie av Karen J. Maher (1997) är att könsskillnaderna, som ofta har kartlagts i enkätstudier där de anställda har fått bedöma sina chefers insatser, är ett resultat av medarbetarnas stereotypa förställningar om hur kvinnliga och manliga chefer är, snarare än en bild av hur de faktiskt beter sig.

Rosabeth Moss Kanter hävdar dessutom att det framför allt är strukturella och kontextuella faktorer i chefernas arbetsmiljö som avgör hur de agerar som ledare (Kanter, 1977). En sådan faktor är t.ex. könsfördelningen inom organisationen, särskilt på ledande positioner. Befinner sig kvinnorna i minoritet kan detta medföra en utsatthet som ökar pressen på dem att anpassa sig efter organisationens rådande normer och regler för hur en chef förväntas agera. Deras utrymme att tillämpa en avvikande ledarstil begränsas därmed (Kanter, 1977; Dahlerup, 1988. Se även Ressner, 1985; Munk Christiansen et al., 2001).

Frågan om huruvida kvinnliga ledare kan förväntas agera på ett annorlunda sätt än män och därmed bidra med nya kompetenser och influenser är således välstuderad och omdebatterad. Det saknas dock i stort sett forskning som kopplar ihop de eventuellt skiljda ledarstrategier som kvinnor och män tilllämpar med hur deras organisationer faktiskt arbetar. Det finns skäl att tro att skillnader i ledarstilar spelar roll, eftersom vi av tidigare forskning om ledningsformer och organisationers prestationer mer generellt kan dra slutsatsen att "management is a key, although complex, determinant of public performance" (Jacobson et al., 2009: 2), men detta säger ingenting om huruvida de specifika skillnader som tillskrivs kvinnors och mäns sätt att leda fungerar som en sådan nyckelfaktor och i så fall på vilket sätt.

Relationsinriktat ledarskap, som vissa forkare hävdar är vanligare bland kvinnor, kan antas vara en mer effektiv ledningsform, eftersom det bidrar till nöjdare personal, bättre coachning och smidigare kommunikation (Bass \& Avolio, 1997). Några av de fåtal studier som empiriskt undersöker sambandet mellan kvinnors och mäns ledarstilar och organisationers prestationer har också visat att företag med en hög andel kvinnliga toppchefer är mer effektiva ekonomiskt än företag där andelen kvinnliga chefer är låg (Krishnan \& Park, 2005; Eagly, 2007).

En annan intressant studie har genomförts av Willow S. Jacobson et al., (2009). Utifrån en modell utvecklad av Meier och O’Toole (2007) mäter de kvinnliga och manliga ledares nätverksaktiviteter med kundgrupper, andra 
ledare och politiska överordnanden i en amerikansk enkätstudie genomförd 1994 och 1998. Dessa aktiviteter visar sig vara en viktig faktor som hänger positivt samman med hur väl organisationen presenterar, mätt i vilken utsträckning den genomför New Public Management (NPM)-reformer, men detta positiva samband föreligger endast för kvinnor som nätverkar med andra ledare. Organisationer som leds av kvinnliga chefer som i huvudsak nätverkar med kundgrupper och medborgare är sämre på att implementera NPM-reformer. Detta resultat kan tolkas som en bekräftelse av tidigare forskning som visar att hög-status-kontakter är viktigare för kvinnor än för män (Kanter, 1977; Vianello \& Moore, 2000; Niklasson, 2005).

I den föreliggande artikeln tar jag avstamp i Jacobsons et al., (2009) slutsats att en organisations externa kontakter har en positiv inverkan på dess arbetssätt. Med tanke på att tidigare forskning framhåller kvinnor som mer relationsinriktade än män är en tänkbar hypotes att kvinnor skulle kunna agera bättre representanter för sina myndigheter utåt och på så sätt förbättra myndigheternas relationer till externa aktörer (Damanpour \& Schneider, 2009), särskilt till hög-status-kontakter som deras politiska överordnanden. Avsikten här är att pröva denna hypotes.

Till skillnad från tidigare studier (se t.ex. Jacobson et al., 2009) är det inte chefernas individuella nätverkande som står i fokus i här, utan organisationernas. Tanken är att i vilken utsträckning, och på vilket sätt en organisation interagerar med externa aktörer påverkas av ledningens inställning till denna typ av kontakter. Om ledningen tydligt signalerar att detta är något som utgör en viktig del av organisationens arbetssätt är det mer sannolikt att närheten i de externa kontakterna växer, både när det gäller omfattningen på kontakterna och hur förtroliga de är. Givet att kvinnor har en mer relationsinriktad ledarstil som tilldelar kommunikation och relationer stor vikt, är det rimligt att anta att organisationer som styrs av kvinnliga chefer kommer att ha närmare relationer till externa aktörer än de som styrs av män. Organisationernas externa kontakter betraktas alltså här som en konsekvens av chefens ledarstil, som i sin tur antas hänga samman med chefens kön. Studien kliver därmed förbi diskussionen om huruvida det föreligger ett samband mellan kön och ledarstilar och tar det viktiga steget att undersöka om ledarnas kön får några konsekvenser för organisationernas arbetssätt. Den tänkta kausala kedjan illustreras i Figur 1.

Fokus i denna studie ligger således på huruvida det föreligger ett kausalt samband mellan myndighetschefens kön och organisationernas relationer med externa aktörer. Dessa relationer betraktas som en aspekt av organisationens arbetssätt. Genom att studera sambandet mellan chefers kön och närheten i myndighetens relationer till externa aktörer bidrar denna studie med ny kun- 
Figur 1. Det förväntade kausala sambandet mellan myndigheters ledning och arbetssätt

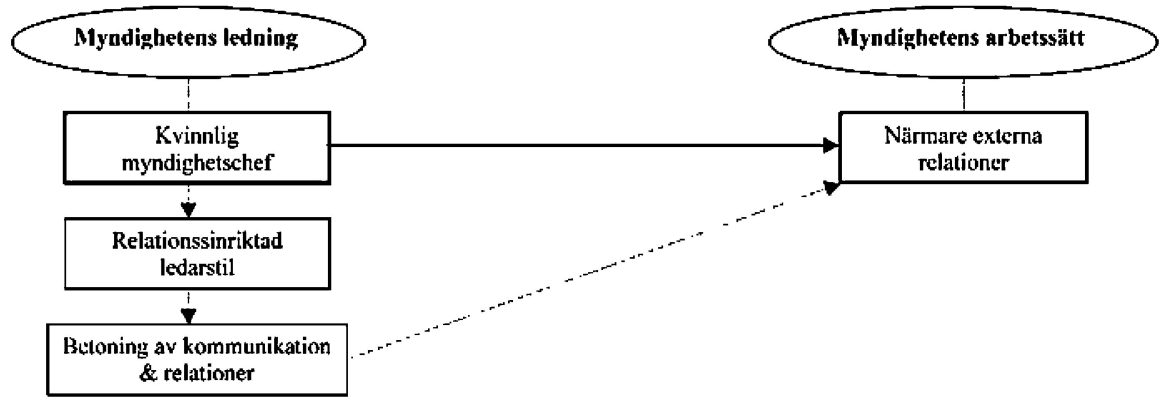

Kommentar: Ovalerna utgörs av kategorier av variabler och boxarna är preciserade variabler inom dessa kategorier. De fetmarkerade, rektangulära textrutorna ("Kvinnlig myndighetschef" och "Närmare externa relationer") indikerar de två variabler som står i fokus i denna studie. Att det är det kausala sambandet mellan dessa två variabler som studeras markeras också med en heldragen pil. De övriga streckade pilarna visar på hur detta kausala samband kan elaboreras; de beskriver hur den oberoende och den beroende variabeln i studien antas hänga ihop.

skap om i vilken utsträckning kompetensargumentet, som inledningsvis uppgavs vara ett skäl till varför det är viktigt att öka andelen kvinnor på ledande befattningar, har empiriskt stöd. De arbetsformer som undersöks här mer specifikt är hur myndigheterna relaterar till sina politiska överordnanden. Det finns naturligtvis även andra relationer som också hade varit intressanta att studera i detta sammanhang, som till t.ex. de mellan myndigheter på nationell, regional och lokal nivå, eller de mellan myndigheter och allmänheten. Att samarbetet mellan myndigheterna och den politiska ledningen fungerar väl är emellertid en förutsättning för att förvaltningen ska kunna implementera demokratiskt förankrade beslut på ett effektivt sätt. I detta tidiga stadium av empiriska studier på forskningsområdet är det därför rimligt att börja med denna högst centrala relation.

\section{Data}

Det empiriska materialet i denna studie grundar sig på en enkätundersökning som genomfördes i Sverige mellan mitten av november 2008 och början av april 2009. ${ }^{1}$ Enkäten vände sig till myndighetschefen, eller den administrativt ansvariga personen på 224 förvaltningsmyndigheter (39 procent styrda av en kvinna). Med förvaltningsmyndigheter åsyftades i detta fall myndigheter som: 1) omfattas av Regeringsformen (RF) 11:6, 2) lyder direkt under regeringen 
och 3) har egen personal. Myndigheter som ingår i urvalet är därmed universitet och högskolor, länsstyrelser, museum och allmänna myndigheter. Av dessa svarade 157 myndigheter (36 procent styrda av en kvinna), vilket motsvarar en svarsfrekvens på 70 procent. Detta kan jämföras med liknande enkäter där motsvarande siffra har legat mellan 30-70 procent. $^{2}$

99 av svaren kommer från myndighetscheferna själva (34 procent av kvinnliga chefer). Övriga enkäter har fyllts i av andra medarbetare, t.ex. ställföreträdande myndighetschefer, ekonomi-, personal-, eller avdelningschefer. Analyserna i denna artikel kommer inte att ta hänsyn till vem som har svarat, eftersom frågorna är av informantkaraktär; de fokuserar på myndigheten och inte på de individuella svarspersonerna (Kvale, 2005). Detta är en fördel i förhållande till tidigare studier som ofta grundar sig på direkta utvärderingar av myndighetschefen (Epstein et al., 1991; Maher, 1997). Genom att be informanterna redogöra för sina erfarenheter och upplevelser av hur myndigheten fungerar i praktiken minskar risken för könsstereotypa svar; det är ganska osannolikt att informanterna, särskilt de som inte själva är myndighetschefer, utgår ifrån huruvida myndigheten styrs av en kvinna eller man i sina svar då det inte finns något $\mathrm{i}$ enkäten som indikerar att detta är relevant. Det är dock viktigt att hålla $\mathrm{i}$ åtanke att datan om myndigheternas arbetssätt grundar sig på självrapporterade uppgifter från en bestämd tidpunkt. Inom ramen för denna studie har det varken varit möjligt att ta fram dokumentation som understödjer angivna interaktionsmönster, eller att följa hur myndigheter eventuellt förändras över tid under en kvinnlig respektive manlig chef.

\section{Fallet Sverige}

Något som utmärker svenska myndigheter är att de, i ett internationellt perspektiv, åtnjuter en relativt stor operationell autonomi (Pollitt \& Bouckaert, 2004). Regeringen har t.ex. inte rätt att blanda sig i hur myndigheterna hanterar enskilda ärenden och myndighetschefen har stor frihet att själv forma myndighetens organisation och arbetsformer (RF 11:7; SFS, 2007: 515). Detta innebär att Sverige är ett lämpligt fall för denna studie, eftersom det finns utrymme för organisationernas arbetssätt att variera beroende på vem som är chef, exempelvis om chefen är en kvinna eller en man (Kanter, 1977; Eagly, 2007; Jacobson et al., 2009). Dessutom är könsfördelningen bland myndighetscheferna relativt jämn i Sverige jämfört med i många andra länder, vilket minskar risken för att kvinnliga chefer befinner sig i en minoritetsposition som tvingar dem att anpassa sig till en traditionellt manlig ledarstil. De utgör en kritisk massa, vilket borde ge dem utrymme att praktisera en alternativ ledarstil om de så önskar (Kanter, 1977). En studie av Sverige kan därför bidra med 
ny och relevant kunskap om hur myndighetschefers kön påverkar förvaltningens sätt att arbeta, särskilt med tanke på att en stor del av tidigare forskning har grundat sig på amerikansk data (Eagly, 2007) och på andra typer av organisationer (Fox \& Schuhmann, 1999).

\section{Närheten i myndigheters relationer till deras politiska överordnanden}

Den beroende variabeln i denna studie - närheten i myndigheters relationer till deras politiska överordnanden - kommer att mätas med hjälp av fem enkätfrågor. Detaljerade beskrivningar av enkätfrågorna finns i appendixet. Tre av dessa frågor berör i vilken utsträckning myndigheten har tillgång till den ansvariga ministern och i vilken omfattning formella och informella kontakter med regeringen och ansvarigt departementet förekommer. Dessa frågor syftar till att mäta omfattningen på myndigheternas kontakter med den politiska ledningen. Övriga två frågor fokuserar på hur högt det ömsesidiga förtroendet gentemot dessa aktörer upplevs vara. Dessa två frågor avser mäta hur god kvaliteten i kontakterna är. Det som betecknas som en nära eller en bra relation i denna studie är alltså relationer som präglas av täta kontakter och ett högt förtroende. Samtliga frågor är signifikant korrelerade med varandra och de har slagits ihop till ett additativt index som löper mellan 0-100, i vilket alla variabler har tilldelats lika stor vikt. Indexet är normalfördelat. Medelvärdet är 65 och medianen 64. Det lägsta noterade värdet är 30 och det högsta 97. Crombachs Alpha för indexet är 0,707. Om kvinnliga chefer är mer socialt kompetenta, samt lägger större vikt vid relationer och kommunikation, och om detta är något som avspeglas i deras sätt att leda organisationen, är det rimligt att anta att myndigheter som styrs av kvinnor kommer att få ett högre värde på detta relationsindex.

\section{Kontroller relaterade till myndighetschefen}

Det finns dock andra saker än myndighetschefens kön som kan tänkas ha en inverkan på hur kontakterna och förtroendet till den politiska ledningen ser ut. Några sådana faktorer är kopplade direkt till myndighetschefen, t.ex. hur länge hon har innehaft sitt nuvarande uppdrag (jmf Jacobson, 2009). De kvinnliga myndiggetscheferna $\mathrm{i}$ studien har i genomsnitt suttit ett år kortare på sina positioner än deras manliga kollegor ( $\mathrm{p}=0,000$, two-tailed $\mathrm{t}$-test). Tidsfaktorn är därför viktig att kontrollera för av två skäl. För det första är det orimligt att förvänta sig att en nytillsatt chef har haft tillräckliga möjligheter att förändra myndighetens relation gentemot den politiska ledningen, eftersom sådana förändringar kan ta tid. Inledningsvis ärver troligen myndighetschefen välvilja 
och konflikter kopplade till denna relation från sin företrädare. För det andra kan man tänka sig att en erfaren myndighetschef har haft längre tid på sig att utveckla en nära relation till politikerna. Chansen att få behålla uppdraget som myndighetschef en längre tid är sannolikt ganska liten om denna relation fungerar dåligt. Vi kan därför förvänta oss att myndighetschefer som har suttit längre på sina positioner får ett högre värde på relationsindexet.

Kvaliteten på relationen mellan myndigheten och den politiska ledningen kan också påverkas av vem som tillsatte myndighetschefen. I Sverige är det inte ovanligt att förvaltningschefer utses bland framstående politiker (Sandahl, 2003). Bland generaldirektörer (chefer för större allmänna myndigheter) och landshövdingar (chefer för länsstyrelserna) är detta rekryteringsmönster särskilt slående (Niklasson, 2007). I många fall är alltså myndighetschefernas partisympatier offentligt kända. Om myndighetschefen utsågs av den nuvarande regeringen (borgerlig), eller av en tidigare regering med samma politiska inriktning, kan därför relationen mellan den politiska ledningen och myndigheten förväntas vara bättre än om hon utsågs av oppositionen. Bland de myndighetschefer som ingår i denna studie utnämndes 60 procent av kvinnorna av en borgerlig regering medan motsvarande siffra bland männen bara är 46 procent ( $\mathrm{p}=0,078$, Kendalls tau-b).

Sambandet mellan myndighetschefens kön och närheten i relationen mellan myndigheten och den politiska ledningen kommer därför att kontrolleras för hur länge myndighetschefen har innehaft sin position och vem som tillsatte henne. Dessa uppgifter är insamlade med hjälp av information från myndigheternas hemsida.

\section{Kontroller relaterade till myndigheten}

Hur relationen till den politiska ledningen ser ut hänger troligen också samman med myndighetens struktur och uppdrag. En stor myndighet med många anställda kan t.ex. lägga mer arbetskraft på att upprätthålla en nära relation till politikerna.

Man kan också tänka sig att politikerna har ett större intresse av att hålla närmare uppsikt över vissa myndigheter, vilket skulle kunna påverka kontaktfrekvensen. Myndigheter som har en stor budget och som kostar staten mycket pengar skulle kunna vara ett exempel. Det är också möjligt att det inte är omfattning av myndigheternas budget i sig som är viktig, utan i hur stor utsträckning det är staten som är ansvarig för den. Utöver myndigheternas antal anställda och totala budget kommer jag därför att kontrollera för hur stor andel av myndighetens inkomster som anslås av regeringen. Dessa uppgifter har samlats in direkt från myndigheterna. 
I vilken grad politikerna riktar särskilt fokus mot vissa myndigheter kan också bero på vilket uppdrag myndigheterna har. Stabsmyndigheter, eller andra myndigheter som i huvudsak har till uppgift att förse regeringen med policyförslag, kunskapsunderlag, information, råd, eller som ska främja vissa frågor kan förväntas rapportera tillbaka till den politiska ledningen oftare än myndigheter som främst sysslar med myndighetsutövning, allmän service och övervakning. Jag kommer därför att genomföra kontroller där jag skiljer ut myndigheter med stabsliknande uppgifter från övriga myndigheter. Informationen baseras på data från enkätundersökningen. Detaljerade beskrivningar av de olika variablerna finns i appendixet.

Ytterligare en kontrollvariabel som är kopplad till myndigheternas struktur är hur könsbalansen ser ut bland de anställda. Även om könsfördelningen inom statsförvaltningen har utjämnats över tid generellt finns det fortfarande sektorer där andelen kvinnor är lägre, både bland de anställda och i ledningen. Eftersom tidigare forskning betonar vikten av att kvinnliga ledare inte befinner sig i en alltför mansdominerad miljö om de ska kunna praktisera en annorlunda ledarstil kontrollerar jag för hur hög andelen kvinnor är bland samtliga anställda på myndigheterna. Dessa siffror har jag tagit fram ur årsredovisningar eller med hjälp av myndigheterna själva.

\section{Resultat}

Det är nu dags att se på vilken effekt myndighetschefens kön har på närheten i myndighetens relation till den politiska ledningen. Hypotesen är att de organisationer som styrs av kvinnor kommer att uppvisa ett högre värde på relationsindexet, dvs. de kommer att ha en närmare relation till regeringen och till det ansvariga departementet, mätt i kontaktfrekvens och graden av ömsesidigt förtroende. Analysen inleds med en redogörelse för de bivariata effekterna (OLS-regressioner) av de inkluderade variablerna på relationsindexet. Efter detta presenteras tre multivariata regressionsmodeller (OLS). I dessa modeller kontrolleras effekten av myndighetschefens kön för andra variabler som är relaterade till 1) myndighetschefen, 2) myndigheten och 3) både till myndighetschefen och till myndigheten.

Tabell 1 visar de bivariata effekter som de oberoende variablerna i studien har på närheten i myndigheters relationer till den politiska ledningen. Det första som är värt att notera är att den oberoende variabel som spelar huvudrollen i denna undersökning - myndighetschefens kön - verkar ha motsatt effekt än väntat. Myndigheter som leds av en kvinnlig chef har inte närmare relationer till regeringen och ansvarigt departement, tvärtom. I den mån det finns en signifikant skillnad (resultatet är bara signifikant på 90 procent konfidensnivå), 
Tabell 1. Bivariata samband på närheten i relationen till den politiska ledningen

\begin{tabular}{lccccc}
\hline $\begin{array}{l}\text { Variabler relaterade till myn- } \\
\text { dighetschefen }\end{array}$ & $\mathbf{b}$ & $\mathbf{t}$ & $\begin{array}{c}\text { Juste- } \\
\text { rat } \mathbf{R}^{2}\end{array}$ & SEE & $\mathbf{N}$ \\
\hline Myndighetschefen är man & $4,63^{*}$ & 1,75 & 0,015 & 14,63 & 132 \\
$\begin{array}{l}\text { Tid på position } \\
\text { Utsedd av oppositionen }\end{array}$ & $-0,58^{*}$ & $-1,73$ & 0,015 & 14,64 & 132 \\
$\begin{array}{l}\text { Variabler relaterade till } \\
\text { myndigheten }\end{array}$ & $-3,13$ & $-1,22$ & 0,004 & 14,69 & 131 \\
\hline $\begin{array}{l}\text { Antal anställda i 100-tal } \\
\text { Ålig budget i miljarder }\end{array}$ & 0,03 & 0,46 & $-0,006$ & 14,84 & 128 \\
$\begin{array}{l}\text { Andel av budget anslagen av } \\
\text { regeringen }\end{array}$ & $-0,02$ & 0,66 & $-0,005$ & 14,85 & 124 \\
$\begin{array}{l}\text { Uppdrag: policyförslag, kuns- } \\
\text { kapsproduktion, information och } \\
\text { råd, eller främjande uppgifter }\end{array}$ & $-8,91^{* * *}$ & $-3,59$ & 0,038 & 14,53 & 123 \\
\begin{tabular}{l} 
Andel kvinnor bland anställda \\
\hline
\end{tabular} & 0,12 & 1,17 & 0,003 & 14,63 & 125 \\
\hline
\end{tabular}

Kommentar: *Signifikant på 90\%-konfidensnivå, **signifikant på 95\%-konfidensnivå, ${ }^{* * *}$ signifikant på $99 \%$-konfidensnivå.

så är det förvaltningarna som har manliga myndighetschefer som uppvisar ett högre värde på relationsindexet. Effekten är dock liten; en manlig chef medför bara en 4,63-stegs ökning på en 100-gradig skala.

En variabel som uppvisar potentiellt större effekt $(b=-0,12)$ berör hur stor andel av myndighetens budget som anslås av regeringen. De myndigheter som i högre grad är ekonomiskt beroende av regeringen tenderar att ha en mer distanserad relation till denna. Skillnaden mellan de myndigheter vars budget utgörs av mindre än en procent av regeringsanslag och de som får nästan hela sin budget därifrån är således 12 steg på det 100-gradiga relationsindexet. Även detta samband går i motsatt riktning mot den förväntade.

Inte heller variabeln som skiljer ut de myndigheter som fyller någon slags stabsfunktion, dvs. de som förser regeringen med policyförslag, information, råd, kunskapsunderlag, eller har någon form av främjade uppgift, påverkar närheten i relationen till den politiska ledningen på förväntat sätt. Stabsmyndigheter uppvisar en signifikant mer distanserad relation till sina politiska överordnande. Detta är ett förvånande resultat, eftersom en hög kontaktfrekvens och ett gott förtroende borde vara en förutsättning för att dessa myndigheter 
ska kunna utföra sitt uppdrag gentemot regeringen på ett tillfredsställande sätt. Här är det dock relevant att kontrollera för universitet och högskolor, eftersom dessa i huvudsak sysslar med kunskapsproduktion utan att för den skull vara stabsmyndigheter. Plockas universitet och högskolor bort ur analysen sjunker också effekten av uppdragsvariabeln $(b=-3,71)$ och den är inte längre signifikant. Resultatet kan därför till viss del bero på att denna variabel fångar in utbildningsinstitutioner som i Sverige är mycket självständiga i förhållande till regeringen och utbildningsdepartementet.

En annan oberoende variabel som också uppvisar en signifikant, men marginell, bivariat effekt på relationsindexet är hur länge myndighetschefen har innehaft sin nuvarande position. Det är dock inte de myndigheter som leds av en mer erfaren chef som uppvisar de närmaste relationerna till den politiska ledningen, vilket antogs inledningsvis. I stället sjunker värdet på relationsindexet med 0,58 steg för varje år som en myndighetschef har suttit på uppdraget. På en 100-gradig skala är denna förändring förvisso försvinnande liten. Det krävs att en chef sitter länge på sitt uppdrag innan denna negativa effekt får någon större betydelse och genomsnittet bland myndighetscheferna i studien är bara fyra år.

Hittills har vi endast tittat på bivariata effekter på närheten i relationen till den politiska ledningen. I Tabell 2 redovisas dock även multivariata sådana.

Modell 1, som kontrollerar effekten av myndighetschefens kön för andra variabler relaterade till myndighetschefen, visar att den positiva, signifikanta effekten av att ha en manlig myndighetschef kvarstår även under kontroll för tjänstetid och vilken typ av regeringen som utsåg honom. Effekten blir till och med starkare $(b=6,05)$.

Myndighetschefens tjänstetid ger dock inte längre någon signifikant effekt. Detta beror på att det finns en tydlig korrelation (Spearmans rho=0,846, $\mathrm{p}=0,000)$ mellan antalet år som myndighetschefen har innehaft sin position och huruvida myndighetschefen är utsedd av en oppositionsregering. Detta innebär att toleransen för dessa två variabler är lägre än 0,6 i Modell 1. Att bortse från vem som utsåg myndighetschefen höjer effekten av tjänstetiden något $(b=-0,74)$, ett resultat som är signifikant på 95 procents konfidensnivå.

Den modell som bäst lyckas förklara graden av närhet i myndigheters relation till den politiska ledningen är emellertid Modell 2 (justerat $\mathrm{R}^{2}=0,193$ ). Här kontrolleras effekten av myndighetschefens kön för variabler som är kopplade till själva myndigheten. Resultatet visar att den positiva effekten av att ha en manlig myndighetschef består och ökar av denna prövning. Myndigheter som styrs av en man får 9,10 steg högre på relationsindexet jämfört med de myndigheter som styrs av en kvinna, tvärtemot vad som var väntat. 
Tabell 2. Regressionsanalyser (OLS) av närheten i relationen till den politiska ledningen

\begin{tabular}{|c|c|c|c|c|c|c|}
\hline & \multicolumn{2}{|c|}{$\begin{array}{l}\text { Modell 1: Myndig- } \\
\text { hetschefsvariabler }\end{array}$} & \multicolumn{2}{|c|}{$\begin{array}{l}\text { Modell 2: Myndig- } \\
\text { hetsvariabler }\end{array}$} & \multicolumn{2}{|c|}{$\begin{array}{c}\text { Modell 3: Samtliga } \\
\text { variabler }\end{array}$} \\
\hline & $b$ & $\mathrm{t}$ & $\mathrm{b}$ & $\mathrm{t}$ & $b$ & $\mathrm{t}$ \\
\hline Konstant & $57,74^{* * *}$ & 9,87 & $64,33^{* * *}$ & 6,47 & $64,50^{* * *}$ & 6,16 \\
\hline Man & $6,05^{* *}$ & 2,26 & $9,10^{* * *}$ & 3,36 & $9,66^{* * *}$ & 3,49 \\
\hline \multicolumn{7}{|l|}{$\begin{array}{l}\text { Myndighetschefsva- } \\
\text { riabler }\end{array}$} \\
\hline Tid på position & $-0,66$ & $-1,47$ & - & - & $-0,32$ & $-0,67$ \\
\hline Utsedd av opposition & $-0,49$ & $-0,14$ & - & - & $-0,14$ & $-0,04$ \\
\hline \multicolumn{7}{|l|}{ Myndighetsvariabler } \\
\hline Anställda i 100-tal & - & - & 0,09 & 0,93 & 0,08 & 0,84 \\
\hline Budget i miljarder & - & - & $-0,04$ & $-0,97$ & $-0,04$ & $-0,92$ \\
\hline $\begin{array}{l}\text { Andel av budget från } \\
\text { regeringen }\end{array}$ & - & - & $-0,11^{* *}$ & $-2,37$ & $-0,11^{* *}$ & $-2,32$ \\
\hline $\begin{array}{l}\text { Uppdrag: policy- } \\
\text { förslag, kunskaps- } \\
\text { produktion, infor- } \\
\text { mation och råd, eller } \\
\text { främjande uppgifter }\end{array}$ & - & - & $-10,11^{* * *}$ & $-3,95$ & $-9,63^{* * *}$ & $-3,70$ \\
\hline $\begin{array}{l}\text { Andel kvinnor av } \\
\text { anställda }\end{array}$ & - & - & 0,14 & 1,28 & 0,14 & 1,25 \\
\hline Justerat $\mathrm{R}^{2}$ & \multicolumn{2}{|c|}{0,036} & \multicolumn{2}{|c|}{0,193} & \multicolumn{2}{|c|}{0,181} \\
\hline SEE & \multicolumn{2}{|c|}{14,45} & \multicolumn{2}{|c|}{13,24} & \multicolumn{2}{|c|}{13,30} \\
\hline $\mathrm{N}$ & \multicolumn{2}{|c|}{131} & \multicolumn{2}{|c|}{113} & \multicolumn{2}{|c|}{112} \\
\hline
\end{tabular}

Kommentar: **Signifikant på 95\%-konfidensnivå. ***Signifikant på 99\%-konfidensnivå. Den beroende variabeln är ett relationsindex som löper mellan 0-100. En detaljerad beskrivning av de olika variablerna finns i appendix.

Myndigheter vars budget övervägande utgörs av anslag från regeringen och myndigheter som har någon slags stabsfunktion som huvuduppgift har liksom i den bivariata analysen signifikanta, negativa effekter på närheten till den politiska ledningen. Utesluts universitet och högskolor ur analysen är dock inte längre effekten av myndigheters huvuduppgift signifikant. I stället framträder betydelsen av två andra variabler: antalet anställda och myndighetens budget. Dessa variabler uppvisar effekter som är signifikanta på 90 procents konfidensnivå. När det gäller antalet anställda så påverkar denna faktor relationen till 
regeringen och det ansvariga departementet på förväntat sätt; för varje 100-tal anställda som en myndighet har ökar relationsindexet med 0,24 steg. Mer resurser i form av större personal verkar alltså underlätta utvecklandet av en nära relation till den politiska ledningen. De största myndigheterna i undersökningen har ca 15.000 anställda, vilket innebär att skillnaden på relationsindexet mellan de största och minsta myndigheterna med bara en anställd kan vara relativt stor. Samtidigt har de flesta myndigheter färre än 200 anställda.

En större budget verkar däremot inte vara en resurs som bidrar till att bygga en närmare relation till den politiska ledningen. I stället sjunker värdet på relationsindexet med 0,09 steg för varje miljard som myndigheten har till sitt förfogande. På en 100-gradig skala framstår detta som en marginell effekt med tanke på att majoriteten av myndigheterna i studien inte har en budget som överskrider en miljard.

I Modell 3 inkluderas så slutligen samliga variabler som ingår i undersökningen. Även under denna kontroll består den positiva effekten av en manlig myndighetschef $(b=9,66)$. Detta gäller även för de två variabler som är kopplade till myndigheten (myndighetens uppdrag och andelen av budgeten som anslås av regeringen) som uppvisade signifikanta effekter i Modell 2. Myndighetschefens tjänstetid är dock inte längre signifikant och det gör ingen skillnad om variabeln om vem som utsåg chefen exkluderas ur analysen. Om universitet och högskolor utesluts förändras resultatet dock på liknande sätt som i Modell 2, dvs. effekten av myndighetens huvuduppgift är inte längre signifikant och i stället framstår antalet anställda och myndigheternas budget som mer relevanta förklaringsfaktorer till närheten i myndigheternas relation till den politiska ledningen.

Sammanfattningsvis visar resultaten i denna empiriska analys att både faktorer som är kopplade till myndighetschefen och till myndigheten påverkar närheten i relationerna till den politiska ledningen. I första hand är det två variabler som uppvisar stabila och signifikanta effekter: myndighetschefens kön och andelen av myndighetens budget som anslås av regeringen.

\section{Avslutande diskussion}

Avslutningsvis återstår att diskutera vad dessa resultat egentligen innebär. Det är tydligt att anställda vid myndigheter upplever relationen mellan deras organisationer och den politiska ledningen olika beroende på om myndighetschefen är en kvinna eller en man. De myndigheter som leds av män uppges ha en närmare relation till regeringen och de ansvariga departementen. Denna skillnad kan inte förklaras med någon av de sju kontrollvariabler som har inkluderas i analyserna här. Effekten består under kontroll för faktorer relaterade 
till myndighetschefens egen person såväl som till myndigheten som helhet. Detta resultat kan förstås på åtminstone två olika sätt. Vilken av dessa följande förklaringar som stämmer bäst åligger framtida forskning att reda ut.

För det första kan det peka på att tidigare forskning har fel och att kvinnor inte tillämpar en mer relationsinriktad ledarstil än män. Argumentet att fler kvinnor borde rekryteras som förvaltningschefer för att de besitter en högre kompetens än män när det gäller hanterandet av kommunikationer och relationer får inte något stöd $\mathrm{i}$ denna empiriska studie. Kvinnor verkar inte medföra att myndigheternas arbetssätt förändras på ett sätt som gör att de utvecklar en närmare relation till viktiga externa aktörer, i det här fallet deras politiska överordnanden.

Ett annat sätt att förstå resultaten är att kvinnor kanske praktiserar en mer relationsinriktad ledarstil, men att skillnaden inte är tillräckligt stor, eller stark för att ge utslag i myndigheternas relationer till regeringen och ansvariga departement. Det kan finnas andra viktigare faktorer som inte har inkluderats i denna analys och som skulle kunna motverka den eventuellt positiva inverkan som kvinnors ledarstil har. En möjlig sådan faktor är manliga nätverk. Det finns mycket forskning som visar att den manliga dominans som länge har rått i samhällets ledande skikt, kombinerat med människors homosociala beteende, har bidragit till att utestänga kvinnor från viktiga informations- och kommunikationsprocesser (Kanter, 1977; Wahl et al., 2001; Holgersson, 2003). Då kvinnor uppfattas som att de kommunicerar på ett annat sätt än män framstår de inte som naturliga diskussionspartners (Ressner, 1985). Förekomsten av manliga nätverk skulle därmed kunna förta en potentiellt positiv effekt av kvinnligt ledarskap. Samtidigt är denna förklaring mindre trolig i ett land som Sverige där det numera finns gott om andra kvinnor att nätverka med, särskilt i den politiska ledningen (Niklasson, 2009). Dessutom är det inte myndighetschefernas personliga nätverk som efterfrågas i den här studien, utan i vilken utsträckning myndigheten som helhet har en nära relation till politikerna. Dessa relationer kan skötas både av kvinnliga och manliga tjänstemän på alla nivåer inom myndigheten och det framstår som något osannolikt att en manlig tjänsteman skulle nekas tillgång till ansvariga politiker, eller ha en mindre förtrolig relation till dessa enbart på grund av att hans myndighetschef är en kvinna.

Sammanfattningsvis är det sålunda oklart i vilken utsträckning vi borde förvänta oss att fler kvinnliga chefer leder till att statsförvaltningen förbättrar sina arbetsmetoder och utvecklar närmare relationer till viktiga externa aktörer. Det behövs mer forskning för att bringa klarhet i denna fråga. Framtida forskning skulle exempelvis kunna undersöka vilken effekt kvinnliga chefer har på myndigheters relationer till andra typer av aktörer än de som har figure- 
rat här, t.ex. relationen till andra myndigheter på olika nivåer eller till allmänheten. Datainsamlingsmetoder som inte enbart förlitar sig på myndigheternas självrapporterade uppgifter om närheten i dessa relationer, utan som även ger en bild av hur motparterna uppfattar interaktionerna skulle också bidra med relevant kunskap. Forskningsläget skulle också kunna föras framåt med hjälp av djupgående fallstudier som följer utvecklingen i en myndighet över tid från det att det sker ett könsskifte på myndighetschefsposten.

Det vi kan slå fast utifrån det empiriska material som har presenterats i denna artikel är att om det är så att kvinnor faktiskt utövar en mer relationsinriktad ledarstil så är detta inte något som automatiskt resulterar i att de anställda på myndigheterna upplever sig ha en närmare relation till deras politiska överordnande. Detta resultat innebär emellertid inte att det är meningslöst att eftersträva en jämnare könsfördelning på chefspositioner i statsförvaltningen. Fler kvinnliga ledare kan fortfarande anses vara ett viktigt mål av principiella skäl. Dessutom kan kvinnliga chefer också ha en viktig roll att spelar som förebilder.

\section{Noter}

1. Enkätstudien är en del av ett postdok-projekt finansierat av Vetenskapsrådet.

2. Enkäten genomfördes inom ramen för det internationella forskningsprojektet COBRA (Comparative Public Organisation Data Base for Research and Analysis), som startades av Geert Bouckaert och Guy Peters år 2001. Hittills har projektet resulterat i liknande enkätstudier i 13 länder.

\section{Litteratur}

Bakker, Jeanette (2000). "Life Choices and Leaders' Informal Networks", pp. 104-119 i Mino Vianello \& Gwen Moore (red.), Gendering Elites; Economic and Political Leadership in 27 Industrialised Societies. London: MacMillan, Ltd.

Bass, Bernard M. \& Bruce J. Avolio (1997). "Shatter the Glass Ceiling: Women May Make Better Managers", pp. 199-210 i K. Grint (red.), Leadership: Classical, Contemporary, and Critical Approaches. Oxford: Oxford University Press.

Bass, Bernard M. et al. (1996). ”The Transformational and Transactional Leadership of Men and Women", Applied Psychology, vol. 45, no. 1, pp. 5-34.

Berg, Elisabeth (2000). Kvinna och chef $i$ offentligt förvaltning. Malmö: Liber AB. Butler, Judith (1993). Bodies That Matter. On the Discursive Limits of "Sex". New York: Routledge. 
Dahl, Robert A. (2000). On Democracy. New Haven: Yale University Press.

Dahlerup, Drude (1988). "From a Small to a Large Minority: Women in Scandinavian

Politics", Scandinavian Political Studies, vol. 11, no. 4, pp. 275-298.

Damanpour, Fariborz \& Marguerite Schneider (2009). "Characteristics of Innovation

and Innovation Adoption in Public Organizations: Assessing the Role of

Managers", J Public Adm. Res. Theory, vol. 19, no. 3, pp. 495-522.

de Beauvoir, Simone [1949](1997). The Second Sex. London: Vintage.

Djerf-Pierre, Monika (2007). "Personkontakter", pp. 225-246 i Anita Göransson (red.),

Maktens kön. Kvinnor och män i den svenska makteliten på 2000-talet. Nora:

Nya Doxa.

Eagly, Alice H. (2007). "Female leadership advantage and disadvantage: resolving the contradictions", Psychology of Women Quarterly, vol. 31, no. 1, pp. 1-12.

Eagly, Alice H. \& Blair T. Johnson (1990). "Gender and leadership style: A metaanalysis", Psychological Bulletin, vol. 108, no. 2, pp. 233-256.

Epstein, Cynthia Fuchs et al. (1991). Ways Men and Women Lead. Harvard Business School Publication Corp. 69, pp. 150-160.

Fox, Richard L. \& Robert A. Schuhmann (1999). "Gender and Local Government:

A Comparison of Women and Men City Managers", Public Administration Review, vol. 59, no. 3 .

Gilligan, Carol (1982). In a Different Voice: Psychological Theory and Women's Development. Cambridge, Mass.: Harvard University Press.

Hirdman, Yvonne (1990). "Genussystemet", SOU 1990:44. Demokrati och makt i Sverige. Maktutredningens huvudrapport. Stockholm: Allmänna förlaget.

Holgersson, Charlotte (2003). "Företagsledare och chefer", pp. 105-123 i Anna Wahl (red.), SOU 2003:15. Mansdominans i företag. Betänkande frän Utredningen om kvinnor på ledande poster i näringslivet. Stockholm: Norstedts Juridik/ Fritzes.

Holmquist, Carin (1997). "Den ömma bödeln. Kvinnliga ledare i åstramningstider", pp. 147-177 i Elisabeth Sundin (red.), SOU 1997:83. Om makt och kön. I spåren av offentliga organisationers omvandling. Stockholm: Fritzes.

Jacobson, Willow S. et al. (2009). "A Woman's Touch? Gendered Management and Performance in State Administration", J Public Adm. Res. Theory: mup017.

Kanter, Rosabeth Moss [1977](1993). Menand Women of the Corporation. New York: Basic Books.

KRUS (2010). Staten leder jämt - fler kvinnor till ledande befattning. Stockholm: KRUS (Kompetensrådet för utveckling i staten).

Kvale, Steinar (2005). Den kvalitativa forskningsintervjun. Lund: Studentlitteratur.

Maher, Karen J. (1997). "Gender-Related Stereotypes of Transformational and Trans actional Leadership", Sex Roles, vol. 37, no. 3/4, pp. 209-225. 
Mansbridge, Jane (1991). Ways Men and Women Lead. Harvard Business School Publication Corp. 69, pp. 150-160.

Marcusson, Lena (2008). Att organisera det statliga åtagandet. Rapport till Förvaltningskommittén. Uppsala: Förvaltningskommittén.

Meier, Kenneth J. \& Laurence J. O’Toole (2007). "Modeling public management Empirical analysis of the management - performance nexus", Public Management Review, vol. 9, no. 4, pp. 503-527.

Mill, John Stuart [1869](1970). The Subjection of Women. Cambridge, Mass.: MIT Press.

Moore, Gwen \& Deborah White (2000). "Interpersonal Contacts", pp. 120-130 i Mino Vianello \& Gwen Moore (red.), Gendering Elites; Economic and Political Leadership in 27 Industrialised Societies. London: MacMillan, Ltd.

Moore, Gwen \& Deborah White (2001). Gender Inequality and National Elite Networks in Twenty-Four Industrialized Societies. Albany: 22.

Munk Christiansen, Peter et al. (2001). Den danske elite. Köpenhamn: Hans Reitzels Forlag A/S.

Niklasson, Birgitta (2005). Contact Capital in Political Careers. Gender and Recruitment of Parliamentarians and Political Appointees. Göteborg: Department of Political Science.

Niklasson, Birgitta (2007). ”Förvaltningseliten”, pp. 365-385 i Anita Göransson (red.), Maktens kön. Nora: Nya Doxa.

Niklasson, Birgitta (2009). ”Den politiska eliten”, pp. 110-130 i Li Bennich-Björkman \& Paula Blomqvist (red.), Mellan folkhem och Europa. Malmö: Liber.

Phillips, Anne (2000). Närvarons politik - den politiska representationen av kön, etnicitet och ras. Lund: Studentlitteratur.

Pollitt, Christopher \& Geert Bouckaert (2004). Public Management Reform. A Comparative Analysis. Oxford: Oxford University Press.

Proposition 2008/2009:1. Utgiftsområde 2. Bilaga 1. Samhällsekonomi och finansförvaltning.

Ressner, Ulla (1985). Den dolda hierarkin. Om demokrati och jämställdhet. Stockholm: Rabén \& Sjögren.

Regeringsformen (RF) 11:6: Rättsskipning och förvaltning.

Regeringsformen (RF) 11:7: Rättskipning och förvaltning.

Rosener, Judy B. (1990). "Ways Women Lead", Harvard Business Review, pp. 119-125. Sandahl, Rolf (2003). Förtjänst och skicklighet-om utnämningar och ansvarsutkrävande av generaldirektörer. DS 2003:7. Stockholm: Fritzes offentliga publikationer, Finansdepartementet.

Svensk författningssamling (SFS) 2007:515. Myndighetsförordning.

Stivers, Camilla (1993). Gender Images in Public Administration: Legitimacy and the Administrative State. Newbury Park, CA.: Sage. 
SOU 2007:107. Opinionsbildande verksamhet och små myndigheter. Delbetänkande av 2006 àrs förvaltning kommitté. Stockholm: Fritzes.

Wahl, Anna (2003). Könsstruktur i organisationer. Lund: Studentlitteratur.

Wahl, Anna et al. (2001). Det ordnar sig. Teorier om organisation och kön. Lund: Studentlitteratur.

Westerberg, Lillemor (1997). "Dubbla rationaliteter - en discussion kring två studier om barnstugor med resultatansvar", pp. 246-272 i Elisabeth Sundin (red.), SOU 1997:87. Om makt och kön. I spåren av offentliga organisationers omvandling. Stockholm: Fritzes.

Vianello, Mino \& Gwen Moore (2000). Gendering Elites. Economic and Political Leadership in 27 Industrialised Societies. London: Macmillan Press Ltd.

Young, Iris Marion (1990). Justice and the Politics of Difference. Princeton: Princeton University Press.

Elektroniska källor

Regeringens hemsida: www.regeringen.se 


\section{Appendix: \\ beskrivning av inkluderade variabler}

Tabell A1. Variabler som är grundade på enkätdata

\begin{tabular}{|c|c|c|c|c|c|c|c|}
\hline VARIABEL & $\begin{array}{c}\text { ENKÄTFRÅ- } \\
\text { GA }\end{array}$ & $\begin{array}{l}\text { SVARSAL- } \\
\text { TERNATIV }\end{array}$ & $\bar{X}$ & $\begin{array}{l}\text { ME- } \\
\text { DIAN }\end{array}$ & $\begin{array}{l}\text { STD. } \\
\text { AV. }\end{array}$ & MIN. & MAX. \\
\hline Relationsindex & $\begin{array}{l}\text { Se relationsin- } \\
\text { dexvariabler 1-5 } \\
\text { nedan }\end{array}$ & $0-100$ & 65 & 64 & 14,8 & 30 & 97 \\
\hline $\begin{array}{l}\text { Relationsindex- } \\
\text { variabel } 1\end{array}$ & $\begin{array}{l}\text { I vilken ut- } \\
\text { sträckning } \\
\text { stämmer } \\
\text { nedanstående } \\
\text { påstående på } \\
\text { myndighetens } \\
\text { uppgifter och } \\
\text { kompetenser } \\
\text { inom dess } \\
\text { verksamhetsom- } \\
\text { råde? }\end{array}$ & $\begin{array}{l}\text { Myndigheten } \\
\text { har direkt till- } \\
\text { gång till minis- } \\
\text { tern i mycket } \\
\text { hög grad (4), i } \\
\text { hög grad, i viss } \\
\text { grad, i låg grad, } \\
\text { inte alls (0), ej } \\
\text { relevant }\end{array}$ & 1,8 & 2,0 & 1,0 & 0 & 4 \\
\hline $\begin{array}{l}\text { Relationsindex- } \\
\text { variabel } 2\end{array}$ & $\begin{array}{l}\text { Hur kan det } \\
\text { ömsesidiga för- } \\
\text { troendet beskri- } \\
\text { vas mellan } \\
\text { myndigheten } \\
\text { och regeringen? }\end{array}$ & $\begin{array}{l}\text { Mycket högt } \\
(4), \text { ganska } \\
\text { högt, varken } \\
\text { högt eller lågt, } \\
\text { ganska lågt, } \\
\text { mycket lågt (0) }\end{array}$ & 3,0 & 3,0 & 0,8 & 1 & 4 \\
\hline $\begin{array}{l}\text { Relationsindex- } \\
\text { variabel } 3\end{array}$ & $\begin{array}{l}\text { Hur kan det } \\
\text { ömsesidiga för- } \\
\text { troendet beskri- } \\
\text { vas mellan } \\
\text { myndigheten } \\
\text { och den poli- } \\
\text { tiska ledningen } \\
\text { på ansvarigt } \\
\text { departement? }\end{array}$ & $\begin{array}{l}\text { Mycket högt } \\
(4) \text {, ganska } \\
\text { högt, varken } \\
\text { högt eller lågt, } \\
\text { ganska lågt, } \\
\text { mycket lågt }(0)\end{array}$ & 3,0 & 3,0 & 0,9 & 0 & 4 \\
\hline
\end{tabular}




\begin{tabular}{|c|c|c|c|c|c|c|c|}
\hline $\begin{array}{l}\text { Relationsindex- } \\
\text { variabel } 4\end{array}$ & $\begin{array}{l}\text { Hur ofta har } \\
\text { myndigheten } \\
\text { formella kon- } \\
\text { takter (led- } \\
\text { ningsmöten } \\
\text { med skriftlig } \\
\text { dagordning) } \\
\text { med regeringen } \\
\text { eller ansvarigt } \\
\text { departement? }\end{array}$ & $\begin{array}{l}\text { En eller flera } \\
\text { ggr i veckan } \\
(6), \text { en eller } \\
\text { flera ggr i } \\
\text { månaden, en } \\
\text { ggn i kvartalet, } \\
\text { två ggr per } \\
\text { år, mindre än } \\
\text { en ggn per år, } \\
\text { aldrig }(0), \text { ej } \\
\text { relevant }\end{array}$ & 2,8 & 2,0 & 1,4 & 0 & 6 \\
\hline $\begin{array}{l}\text { Relationsindex- } \\
\text { variabel } 5\end{array}$ & $\begin{array}{l}\text { Hur ofta har } \\
\text { myndigheten } \\
\text { informella } \\
\text { kontakter (led- } \\
\text { ningsmöten } \\
\text { utan skriftlig } \\
\text { dagordning, } \\
\text { telefonsamtal, } \\
\text { e-post, etc.) } \\
\text { med regeringen } \\
\text { eller ansvarigt } \\
\text { departement? }\end{array}$ & $\begin{array}{l}\text { En eller flera } \\
\text { ggr i veckan } \\
(6), \text { en eller } \\
\text { flera ggr i } \\
\text { månaden, en } \\
\text { ggn i kvartalet, } \\
\text { två ggr per } \\
\text { år, mindre än } \\
\text { en ggn per år, } \\
\text { aldrig }(0), \text { ej } \\
\text { relevant }\end{array}$ & 5,0 & 5,0 & 0,8 & 1 & 6 \\
\hline $\begin{array}{l}\text { Huvudsakligt } \\
\text { uppdrag }\end{array}$ & $\begin{array}{l}\text { Detta är en } \\
\text { nominalskalig } \\
\text { variabel som } \\
\text { har kodats om } \\
\text { till en dummy. }\end{array}$ & $\begin{array}{l}\text { Tillsyn/ } \\
\text { reglering/kon- } \\
\text { troll, annan } \\
\text { myndighets- } \\
\text { utövning, } \\
\text { allmänna } \\
\text { samhällstjän- } \\
\text { ster, affärs- och } \\
\text { industritjänster } \\
\text { (1), politikut- } \\
\text { formning, in- } \\
\text { formation och } \\
\text { rådgivning, } \\
\text { kunskaps- } \\
\text { produktion, } \\
\text { samt främjande } \\
\text { uppgifter (2). }\end{array}$ & 1,5 & 1,0 & 0,5 & 1 & 2 \\
\hline
\end{tabular}


Tabell A2. Variabler som ej är grundade på enkätdata

\begin{tabular}{|c|c|c|c|c|c|c|}
\hline VARIABEL & $\begin{array}{l}\text { SVARSALTER- } \\
\text { NATIV }\end{array}$ & $\bar{X}$ & MEDIAN & STD. AV. & MIN. & MAX. \\
\hline Kön & $\begin{array}{l}\text { Kvinna (1), } \\
\operatorname{man}(2)\end{array}$ & 1,6 & 2,0 & 0,5 & 1 & 2 \\
\hline Tid på position & Anges i antal år & 4,1 & 3,0 & 3,7 & 0 & 25 \\
\hline $\begin{array}{l}\text { Utsedd av } \\
\text { oppositionen }\end{array}$ & $\operatorname{Nej}(1)$, ja (2) & 1,5 & 1,0 & 0,5 & 1 & 2 \\
\hline Antal anställda & Anges i 100-tal & 8,0 & 1,6 & 19,5 & 0 & 147 \\
\hline Årlig budget & $\begin{array}{l}\text { Anges i } \\
\text { miljarder }\end{array}$ & 5,2 & 0,2 & 38,2 & 0 & 445 \\
\hline $\begin{array}{l}\text { Andel budget } \\
\text { anslagen av } \\
\text { regeringen }\end{array}$ & $\begin{array}{l}\text { Mindre än } 50 \% \\
(1), \text { minst } 50 \% \\
\text { (2) }\end{array}$ & 71,9 & 78,6 & 26,9 & 0 & 100 \\
\hline $\begin{array}{l}\text { Andel kvinnor } \\
\text { bland anställda }\end{array}$ & Anges i procent & 55,9 & 56,0 & 13,0 & 20 & 100 \\
\hline
\end{tabular}

